\title{
Comparison of ECG, laboratory and echocardiographic parameters in patients with acute myocarditis at acute attack and clinical remission
}

\section{Akut atak ve klinik remisyonda akut miyokarditli hastalarda EKG, laboratuvar ve ekokardiyografik parametrelerin karşılaştırılması}

\author{
Mehmet Inanir ${ }^{1^{*}}$ (D), Müjgan Gürler ${ }^{2}$ (D), Ramazan Kargın ${ }^{3}$ (D), Emrah Erdal ${ }^{4}$ (iD \\ ${ }^{1}$ Bolu Abant Izzet Baysal University, Cardiology Department, Bolu, Turkey \\ ${ }^{2}$ Bolu Abant İzzet Baysal University Faculty of Medicine, Internal Medicine, Bolu, Turkey \\ ${ }^{3}$ Health Sciences University, Kosuyolu Kartal Heart Training and Research Hospital, Cardiology, Istanbul, Turkey \\ ${ }^{4}$ Bolu Abant İzzet Baysal University Faculty of Medicine, Cardiology, Bolu, Turkey \\ * Corresponding author: Mehmet Inanir E-mail: mdmehmetinanir@yahoo.com ORCID: 0000-0003-1784-3584 \\ Received: 3 January 2020 Accepted: 13 March 2020
}

\begin{abstract}
Aim: The pathogenesis of myocarditis, which has high morbidity and mortality in childhood and adolescence, has not been fully elucidated. The pathogenesis of acute myocarditis is a complex process in which multiple agents play a role. We aimed to compare ECG, laboratory and echocardiographic parameters of patients during acute exacerbation of myocarditis and clinical remission.
\end{abstract}

Material and Method: 144 patients (124 males, 20 females) with an acute myocarditis episode were included in the study (28 \pm 5 ). These patients were called for control during the clinical remission period of 3-12 months. The ECG, laboratory and echocardiographic parameters of the patients were compared during acute exacerbation and clinical remission. QT and Tp-e ECG parameters were measured. In addition to routine biochemistry and hemogram parameters, troponin I, uric acid, CRP, sedimentation, TSH and cholesterol levels were measured. Left ventricular ejection fraction was measured as an echocardiographic parameter.

Results: When compared with the clinical remission Tp-e interval ( $p: 0.032), Q T-m a x(p=0.014), Q T-m i n(p=0.001), T S H(p<0.001)$, Trop $(p<0.00)$, Urea $(p=0.028)$, Alt $(p=0.010)$, Ast $(p<0.001)$, Wbc $(p<0.001), H b(p<0.001), H t c(p<0.001), \operatorname{Rdw}(p<0.001), P l t$ $(p<0.001), \operatorname{Mpv}(p<0.001), \operatorname{Neu}(p=0.003), \operatorname{Lym}(p=0.013)$, Mon $(p<0.001), \operatorname{Eo}(p=0.003), \operatorname{Pdw}(p<0.001), \operatorname{CRP}(p=0.001), \operatorname{ESR}(p<0.001)$, and HDL-C $(\mathrm{p}=0.002)$ were significantly changed in patients with acute attack myocarditis.

Conclusion: ECG parameters, inflammation markers, and HDL cholesterol levels were significantly improved in the clinical remission in addition to the left ventricular ejection fraction during acute exacerbation of the patients. LVEF, ECG parameters, inflammation markers, TSH and HDL cholesterol levels were thought to be important in terms of clinical course and pathogenesis of the disease.

Keywords: biochemical, ECG, echocardiography, myocarditis, remission

○ 2020 by the authors; licensee MEDITAGEM Ltd., Turkey. This article is an open access article distributed under the terms and conditions of the Creative Commons Attribution License (http://creativecommons.org/licenses/by/4.0/). 


\section{öz}

Amaç: Çocukluk ve ergenlikte yüksek morbidite ve mortaliteye sahip miyokardit patogenezi tam olarak aydınlatılamamıştır. Akut miyokardit patogenezi, çoklu ajanların rol oynadığı karmaşık bir süreçtir. Miyokarditin akut alevlenmesi ve klinik remisyon sırasında EKG, laboratuvar ve ekokardiyografik parametreleri karşılaştırmayı amaçladık.

Materyal ve Yöntem: Akut miyokardit atağı olan 144 hasta (124 erkek, 20 kadın) çalışmaya dahil edildi (28 \pm 5). Bu hastalar 3-12 aylık klinik remisyon döneminde kontrol altına alındı. Akut alevlenme ve klinik remisyon sırasında hastaların EKG, laboratuvar ve ekokardiyografik parametreleri karşılaştırıldı. QT ve Tp-e gibi EKG parametreleri ölçüldü. Rutin biyokimya ve hemogram parametrelerine ek olarak troponin I, ürik asit, CRP, sedimantasyon, TSH ve kolesterol düzeyleri ölçüldü. Sol ventrikül ejeksiyon fraksiyonu ekokardiyografik parametre olarak ölçüldü.

Bulgular: Klinik remisyon ile karşılaştırıldığında, akut atak miyokarditli hastalarda Tp-e aralığı (p: 0,032), QT-max ( $p=0,014), Q T-$ $\min (p=0,001), \operatorname{TSH}(p<0,001)$, Trop $(p<0,00)$, Üre $(p=0,028)$, Alt $(p=0,010)$, Ast $(p<0,001), W b c(p<0,001), H b(p<0,001), H t c(p$ $<0,001)$, Rdw ( $<<0,001)$, Plt $(p<0,001)$, Mpv $(p<0,001)$, Neu $(p=0,003)$, Lym $(p=0,013)$, Mon $(p<0,001)$, Eo $(p=0,003)$, Pdw $(p$ $<0,001), \operatorname{CRP}(p=0,001), \operatorname{ESR}(p<0,001)$, and HDL-C ( $p=0,002)$ önemli ölçüde değişmiştir.

Sonuç: EKG parametreleri, inflamasyon belirteçleri ve HDL kolesterol düzeyleri, hastaların akut alevlenmesi sırasında sol ventrikül ejeksiyon fraksiyonuna ek olarak klinik remisyonda önemli ölçüde iyileşti. LVEF, EKG parametreleri, inflamasyon belirteçleri, TSH ve HDL kolesterol düzeylerinin hastalığın klinik seyri ve patogenezi açısından önemli olduğu düşünülmektedir.

Anahtar kelimeler: biyokimyasal, EKG, ekokardiyografi, miyokardit, remisyon

\section{INTRODUCTION}

Myocarditis is an inflammation of the myocardium, which is the heart muscle. Acute myocarditis is often caused by viral diseases, but less commonly it can be caused by noninfectious etiologies [1]. The incidence of myocarditis varies between $1 \%$ and $9 \%$ in postmortem examinations [2].

Its clinical presentation is very variable and can range from thin chest pain or fever to life-threatening congestive heart failure or even sudden cardiac death. While the classical myocarditis patient presents with a preceding viral illness followed by heart failure symptoms, clinical presentations range from mild chest pain with normal systolic function to cardiogenic shock and electrophysiological disturbances [35]. It is difficult to diagnose and treatment is usually supportive [6].

The pathogenesis of myocarditis, which has high morbidity and mortality, has not been fully elucidated. The pathogenesis of acute myocarditis is a complex process in which multiple agents play a role.

We aimed to compare ECG, laboratory and echocardiographic parameters of patients during acute exacerbation of myocarditis and clinical remission.

\section{MATERIALS AND METHODS}

This study was carried out cross-sectionally in the cardiology department of Kartal Koşuyolu Heart Diseases Training and Research Hospital between January 2015 and May 2016.
Our study consisted of 144 clinical acute myocarditis patients with a mean age of 28 (16-40) who had upper respiratory tract infection (etc.) were selected. The socioeconomic level of the patients was compatible with the environment in which it lived and was not lower. These patients had a high Troponin-I level. Coronary angiography was performed and normal was detected. These patients were called for control during the clinical remission period (within 3-12 months). ECG, laboratory tests and echocardiography were performed for the patients who came to control.

The diagnosis of acute myocarditis was based on the inclusion of at least one of the following parameters.

1- Increase of cardiac damage biomarkers,

2- Electrocardiographic findings which are suggesting cardiac damage,

3- Abnormal cardiac function on echocardiography or cardiac magnetic resonance imaging [7].

Transthoracic echocardiography was performed in the left lateral decubitus position with a $2.5-3.5 \mathrm{MHz}$ phase-array transducer probe (GE Vingmed, Horten, Norway Vingmed System 3). All echocardiographic parameters were measured off-line and the mean of 3 heart cavities was used. Left ventricular ejection fraction, diastolic and systolic end volumes were calculated by the Simpson modified method [8]. Venous blood samples were obtained from the antecubital ven for fasting routine laboratory tests. Routine biochemistry, hemogram, troponin-I, uric acid, CRP, 
sedimentation, TSH and cholesterol levels were measured in our hospital's laboratory (Roche Diagnostics, Mannheim, Germany Hitachi 747).

\section{EXCLUSION CRITERIA}

The following diseases were excluded in the differential diagnosis of acute myocarditis:

1. Liver dysfunction,

2. Chronic lung disease,

3. Hemolytic disorders,

4. Malignities,

5. Concomitant inflammatory diseases (infections and autoimmune diseases),

6. Previous myocardial infarction,

7. Coronary artery disease

\section{STATISTICAL ANALYSIS}

Statistical analyzes were performed using the IBM-SPSS Statistics version 20 software (SPSS Inc., Chicago, Illinois). Clinical and laboratory data of patients were expressed as \pm standard deviation and percentage (\%). The paired simple test was used to evaluate the statistical significance of the difference between the groups. The results were accepted at $\mathrm{p}<0.05$ significance level.

\section{ETHICAL APPROVAL}

All patients provided written informed consent. There is ethics committee approval from Kartal Koşuyolu Heart Disease Training and Research Hospital for the study. This study was published as an oral presentation at the14 th International Update in Cardiology and Cardiovascular Surgery (UCCVS) Congress (April 7, 2018).

\section{RESULTS}

When compared with the clinical remission Tp-e interval (76.8 \pm 0.27 to $72 \pm 0.23 \mathrm{msn}, \mathrm{p}=0.032$ ), QT-max (351.2 \pm 0.54 to $338.4 \pm 0.73 \mathrm{msn}, \mathrm{p}=0.014)$, QT-min $(331.6 \pm 0.53$ to $314.8 \pm 0.76 \mathrm{msn}, \mathrm{p}=0.001)$, TSH $(1.88 \pm 0.46$ to $1.17 \pm 0.12$ $\mathrm{ulU} / \mathrm{mL}, \mathrm{p}<0.001)$, Trop $(16.20 \pm 2.11$ to $0.03 \pm 0.15 \mathrm{ng} / \mathrm{mL}$, $\mathrm{p}<0.00$ ), Urea( $25.60 \pm 7.66$ to $27.73 \pm 7.63 \mathrm{mg} / \mathrm{dL}, \mathrm{p}=0.028$ ), Alt (49.61 \pm 55.36 to $36.12 \pm 28.02 \mathrm{U} / \mathrm{L}, \mathrm{p}=0.010)$, Ast (57.71 \pm 34.85 to $26.09 \pm 9.08 \mathrm{U} / \mathrm{L}, \mathrm{p}<0.001), \mathrm{Wbc}(9.69 \pm 3.04$ to $7.68 \pm 2.15$ $10 \wedge 3 / \mu \mathrm{L}, \mathrm{p}<0.001), \mathrm{Hb}(13.73 \pm 1.42$ to $14.76 \pm 1.69 \mathrm{~g} / \mathrm{dL}$, $\mathrm{p}<0.001)$, Htc $(40.72 \pm 4.25$ to $44.30 \pm 4.63 \%, \mathrm{p}<0.001)$, Rdw $(14.57 \pm 1.53$ to $13.72 \pm 1.29 \%, p<0.001)$, Plt $(221.58 \pm 54.85$ to $257.87 \pm 53.2910 \wedge 3 / \mu \mathrm{L}, \quad \mathrm{p}<0.001), \quad \mathrm{Mpv} \quad(7.81 \pm 1.14$ to $8.70 \pm 0.96 \mathrm{fL}, \mathrm{p}<0.001)$, Neu $(7.42 \pm 5.76$ to $4.63 \pm 1.69$ $10 \wedge 3 / \mu \mathrm{L}, \mathrm{p}=0.003), \operatorname{Lym}(1.97 \pm 0.67$ to $2.23 \pm 0.5310 \wedge 3 / \mu \mathrm{L}$, $\mathrm{p}=0.013)$, Mon $(0.95 \pm 0.38$ to $0.59 \pm 0.2010 \wedge 3 / \mu \mathrm{L}, \mathrm{p}<0.001)$, Eo $(0.12 \pm 0.12$ to $0.17 \pm 0.1210 \wedge 3 / \mu \mathrm{L}, \mathrm{p}=0.003), \quad \mathrm{Pdw}$
Table 1. ECG parameters

\begin{tabular}{|c|c|c|c|}
\hline ECG parameters & $\begin{array}{c}\text { Acute attack } \\
(\mathrm{n}: 144)\end{array}$ & $\begin{array}{c}\text { Clinical remission } \\
(\mathrm{n}: 142)\end{array}$ & P value \\
\hline \multicolumn{4}{|c|}{ MEAN \pm SD } \\
\hline Tp-e, msn & $76.8 \pm 0.27$ & $72 \pm 0.23$ & 0.032 \\
\hline QT, msn & $339.6 \pm 0.52$ & $329.6 \pm 0.74$ & 0.051 \\
\hline QT-max, msn & $351.2 \pm 0.54$ & $338.4 \pm 0.73$ & 0.014 \\
\hline QT-min, msn & $331.6 \pm 0.53$ & $314.8 \pm 0.76$ & 0.001 \\
\hline QTc, msn & $383.62 \pm 29.97$ & $387.47 \pm 20.16$ & 0.403 \\
\hline
\end{tabular}

QT: QT time, QTc: QT time corrected, QT-max: QT maximum time, QT-min: QT minimum time, Tp-e: T wave peak and end.

Table 2. Biochemical parameters

\begin{tabular}{|c|c|c|c|}
\hline $\begin{array}{l}\text { Biochemical } \\
\text { parameters }\end{array}$ & $\begin{array}{c}\text { Acute attack } \\
\text { (n:144) }\end{array}$ & $\begin{array}{c}\text { Clinical remission } \\
\text { (n: 142) }\end{array}$ & P value \\
\hline \multicolumn{4}{|c|}{$\mathrm{MEAN} \pm \mathrm{SD}$} \\
\hline Pulse, beats/min & $82.78 \pm 15.88$ & $79.33 \pm 13.11$ & 0.221 \\
\hline TSH, ulU/mL & $1.88 \pm 0.46$ & $1.17 \pm 0.12$ & $<0.001$ \\
\hline Uric acid, mg/dL & $6.01 \pm 0.78$ & $6.49 \pm 1.48$ & 0.001 \\
\hline Trop, ng/mL & $16.20 \pm 2.11$ & $0.03 \pm 0.15$ & $<0.001$ \\
\hline Urea, mg/dL & $25.60 \pm 7.66$ & $27.73 \pm 7.63$ & 0.028 \\
\hline $\mathrm{Cr}, \mathrm{mg} / \mathrm{dL}$ & $0.78 \pm 0.16$ & $0.77 \pm 0.13$ & 0.647 \\
\hline Alt, U/L & $49.61 \pm 55.36$ & $36.12 \pm 28.02$ & 0.010 \\
\hline Ast, U/L & $57.71 \pm 34.85$ & $26.09 \pm 9.08$ & 0.000 \\
\hline Wbc: $10^{\wedge} 3 / \mu \mathrm{L}$ & $9.69 \pm 3.04$ & $7.68 \pm 2.15$ & 0.000 \\
\hline Hb, g/dL & $13.73 \pm 1.42$ & $14.76 \pm 1.69$ & 0.000 \\
\hline Htc, $\%$ & $40.72 \pm 4.25$ & $44.30 \pm 4.63$ & 0.000 \\
\hline Rdw, \% & $14.57 \pm 1.53$ & $13.72 \pm 1.29$ & 0.000 \\
\hline Plt, $10^{\wedge} 3 / \mu \mathrm{L}$ & $221.58 \pm 54.85$ & $257.87 \pm 53.29$ & 0.000 \\
\hline Mpv, fL & $7.81 \pm 1.14$ & $8.70 \pm 0.96$ & 0.000 \\
\hline Neu, $10^{\wedge} 3 / \mu \mathrm{L}$ & $7.42 \pm 5.76$ & $4.63 \pm 1.69$ & 0.003 \\
\hline Lym, $10 \wedge 3 / \mu \mathrm{L}$ & $1.97 \pm 0.67$ & $2.23 \pm 0.53$ & 0.013 \\
\hline Mon, $10^{\wedge} 3 / \mu \mathrm{L}$ & $0.95 \pm 0.38$ & $0.59 \pm 0.20$ & 0.000 \\
\hline Eo, $10^{\wedge} 3 / \mu \mathrm{L}$ & $0.12 \pm 0.12$ & $0.17 \pm 0.12$ & 0.003 \\
\hline Pdw, \% & $17.40 \pm 0.91$ & $16.64 \pm 0.45$ & 0.000 \\
\hline CRP, mg/dL & $14.77 \pm 6.93$ & $0.59 \pm 0.35$ & 0.001 \\
\hline ESR, sn & $42.33 \pm 19.92$ & $10.40 \pm 10.59$ & 0.000 \\
\hline Glu, mg/dL & $99.29 \pm 12.08$ & $99.86 \pm 14.74$ & 0.898 \\
\hline LDL-C, mg/dL & $120.75 \pm 34.58$ & $127.83 \pm 38.74$ & 0.439 \\
\hline HDL-C, mg/dL & $34.67 \pm 10.45$ & $47.50 \pm 8.69$ & 0.002 \\
\hline TRIG-C, mg/dL & $142.33 \pm 57.59$ & $180.58 \pm 82.74$ & 0.198 \\
\hline TOTAL-C, mg/dL & $184.08 \pm 50.03$ & $211.83 \pm 46.70$ & 0.067 \\
\hline
\end{tabular}

ALT: Alanine Transaminase, AST: Aspartate Transaminase, Cr: Creatinine, CRP: C Reactive Protein, Eo: Eosinophyl, ESR: Erytrocyte Sedimentation Rate, HB: Hemoglobin, HDL-C: High Density Lipoprotein Cholesterol, Htc: Hematocrite, Glu: Glucose, LDL-C: Low Density Lipoprotein Cholesterol, Lym: Lymphocyte, Mon: Monocyte, MPV: Mean Platelet Volume, Neu: Neutrophil, PDW: Platelet Distibution Width, PLT: Platelet, RDW: Red cell distribution width, TRIG-C: Trigliseride Cholesterol, Total-C: Total Cholesterol, Trop: Troponine, TSH: Thyroid Stimulating Hormone, WBC: White Blood Cell.

(17.40 \pm 0.91 to $16.64 \pm 0.45 \%, p<0.001), C R P(14.77 \pm 6.93$ to $0.59 \pm 0.35 \mathrm{mg} / \mathrm{dL}, \mathrm{p}=0.001)$, ESR $(42.33 \pm 19.92$ to $10.40 \pm 10.59$ sn, $\mathrm{p}<0.001)$, and HDL-C $(34.67 \pm 10.45$ to $47.50 \pm 8.69 \mathrm{mg} / \mathrm{dL}, \quad \mathrm{p}=0.002) \quad$ were significantly changed in patients with acute attack myocarditis (Table 1 and 2). 


\section{ECHOCARDIOGRAPHIC FINDINGS (EF\%)}

In our study, the acute exacerbation of patients with acute myocarditis and the clinical remission LVEF after 3-12 months were $62.1 \%$ and $64.8 \%$, respectively. No statistical analysis was performed.

\section{DISCUSSION}

In this study, we detected that ECG parameters (Tp-e, QTmax, QT-min), hemogram parameters (Wbc, Hb, Htc, Rdw, Plt, Mpv, Neu, Lym, Mon, Eo, Pdw), biochemical parameters (Tsh, Uric acid, Troponin, Alt, Ast, ESR, HDL-C) and echocardiographic parameters (EF) significantly found in acute attack myocarditis. As far as we know in the literature, although ECG, laboratory, and echo parameters were investigated in patients with myocarditis, no acute attack and clinical remission comparison studies have been performed.

Despite its rarity, myocarditis is a significant etiology of acute and chronic heart failure, often leading to dilated cardiomyopathy and the need for heart transplantation [9]. Also, myocarditis is one of the most important causes of sudden heart death in the young patient population [10]. Acute myocarditis is a major cause of morbidity and mortality.

An electrocardiogram (ECG) is routinely evaluated to assess electrical imbalance in myocarditis [11,12]. ECG abnormalities have been reported in $90 \%$ of acute myocarditis patients [13]. Myocarditis may cause sudden heart death in patients without structural heart disease. The most common reason for this is malignant ventricular arrhythmias. Tp-e ratio and Tp-e / QT ratio have been used as a new electrocardiographic marker in ventricular repolarization distribution $[14,15]$. Increased Tp-e interval and Tp-e / QT ratio are associated with malignant ventricular arrhythmias [16-18]. Prolongation of the QT interval has also been suggested as a risk factor for ventricular arrhythmia and death $[19,20]$.

In our study, Tp-e, QT-max, and QT-min levels were found to be statistically significant in acute attack myocarditis compared to clinical remission. In the study conducted by Ucar et al. [21] found that the QT and Tp-e intervals were higher in acute myocarditis compared to the control group. 30 patients with myocarditis and 25 healthy age-matched control groups were included in the study of Güneş $\mathrm{HM}$ et al. [22] when compared with the control group, QT and Tp-e intervals, Tp-e/QT, and Tp-e/QTc ratios were significantly higher in patients with myocarditis.
As shown by our study, the troponin level, which was found to be higher in the acute attack myocarditis period, indicates myocardial damage.

Myocarditis is an inflammatory disease of the myocardium. The inflammation parameters (CRP, uric acid, sedimentation rate, leucocyte, etc.) were high in our study. Sharma et al. [23] showed that inflammatory biomarkers are associated with the severity of myocarditis (especially fulminant myocarditis). High CRP levels have been reported to be a risk factor for the development of fulminant myocarditis $[24,25]$. In a study by Gironès et al. [26] found that uric acid levels increased in myocarditis patients in 2014. During the acute attack of myocarditis, inflammatory markers such as CRP and erythrocyte sedimentation rate may increase [25].

In addition, TSH and HDL cholesterol levels were found to be statistically significant during the acute myocarditis attack in our study according to the period of remission. The low level of HDL cholesterol in the acute period may suggest a negative acute phase reactant. Low HDL cholesterol during an acute attack may play a role in the pathogenesis of the disease.

Echocardiography is a very vital tool in the evaluation of patients with acute myocarditis [27]. Echocardiography is a valuable test to evaluate the presence of ejection fraction (EF) and accompanying valve pathology. In our study, although EF was lower in acute attack myocarditis, it was not statistically significant.

Previous studies were organized as patients and control groups but in our study, comparisons were made during the acute episode and clinical remission of the same patient groups.

\section{LIMITATIONS}

The fact that our study is single-centered and not randomized and the number of patients is low are the main limiting factors.

In addition, myocarditis was diagnosed;

- Not conducting a molecular level study (eg PCR)

- No culture and serological testing

- No cardiac biopsy

- Cardiac MRI has not been performed.

This relationship needs to be supported by longer, more comprehensive and multicentred studies.

\section{CONCLUSION}

The incidence of myocarditis is approximately 10-22 / 100,000 people. Myocarditis is an inflammatory disease of 
the myocardium. Timely diagnosis, prognosis and definitive treatment of myocarditis are important for the clinician. Despite advances in new diagnostic procedures, the diagnosis of acute myocarditis remains a major challenge.

In our study, Tp-e, QT-max, and QT-min were found to be significantly higher in patients with acute myocarditis than in clinical remission. There was no significant difference in QTc. The inflammation parameters (CRP, uric acid, sedimentation rate, leucocyte, etc.) were high in our study. In addition, TSH and HDL cholesterol levels were found to be statistically significant during the acute myocarditis attack in our study according to the period of remission.

In acute myocarditis, ECG changes, laboratory parameters, and echocardiography can be very useful in clinical practice to decide on appropriate treatment, length of hospital stay, and frequency of follow-up.

However, prospective studies with larger numbers of patients are needed to evaluate these parameters in myocarditis.

\section{DECLARATION OF CONFLICT OF INTEREST}

The authors received no financial support for the research and/or authorship of this article. There is no conflict of interest.

\section{REFERENCES}

1. Al-Akchar M, Kiel J. Acute Myocarditis. 2019 Dec 16. StatPearls [Internet]. Treasure Island (FL): StatPearls Publishing; 2020 Jan-. Available from http://www.ncbi.nlm.nih.gov/books/NBK441847/

PubMed PMID: 28722877.

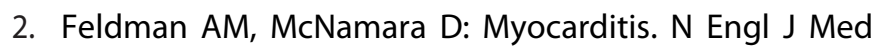
2000; 343: 1388-98.

3. Batra AS, Epstein D, Silka MJ. The clinical course of acquired complete heart block in children with acute myocarditis. Pediatr Cardiol 2003; 24(5): 495-7. (doi: 10.1007/s00246-002-0402-2).

4. Chang YJ, Chao HC, Hsia SH, Yan DC. Myocarditis presenting as gastritis in children. Pediatr Emerg Care 2006; 22(6): 439-40. (doi: 10.1097/01.pec.0000221346.64991.e7).

5. Durani Y, Egan M, Baffa J, Selbst SM, Nager AL. Pediatric myocarditis: presenting clinical characteristics. Am J Emerg Med 2009; 27(8): 942-7. (doi: 10.1016/j.ajem.2008.07.032).
6. Jois A, Zannino D, Curtis N, Cheung M, Burgner DP, Chen $\mathrm{KYH}$. Arterial Structure and Function Following Viral Myocarditis. Pediatr Cardiol. 2019 Jan; 40(1): 133-7.

7. Leslie TC, Kirk UK. Part VIII. Disease of the heart, pericardium, and pulmonary vasculature bed.67; Myocarditis. Edited by: Douglas LM, Douglas PZ, Peter L, Robert O. Bonow. Founding editor and online editor: Eugene B. Braunwald's Heart Disease: A Textbook of Cardiovascular Medicine. Tenth edition. Philadelphia; 2015. pp. 1591.

8. Lang RM, Bierig M, Devereux RB, et al. Recommendations for chamber quantification: a report from the American Society of Echocardiography's Guidelines and Standards Committee and the Chamber Quantification Writing Group, developed in conjunction with the European Association of Echocardiography, a branch of the European Society of Cardiology. J Am Soc Echocardiogr 2005; 18: 440-63.

9. Savla J, Lin KY, Lefkowitz DS, Paridon SM, Gaynor JW, Hammond R, Shaddy RE, Rossano JW (2014) Adolescent age and heart transplantation outcomes in myocarditis or congenital heart disease. J Heart Lung Transplant 33(9): 943-9. (doi: 10.1016/j.healun.2014.04.018).

10. Al-Khatib SM, Stevenson WG, Ackerman MJ, Bryant WJ, Callans DJ, Curtis AB, et al. 2017 AHA/ACC/HRS guideline for management of patients with ventricular arrhythmias and the prevention of sudden cardiac death: Executive summary: A Report of the American College of Cardiology/American Heart Association Task Force on Clinical Practice Guidelines and the Heart Rhythm Society. Heart Rhythm. 2018 Oct;15(10):e190-e252. (doi: 10.1016/j.hrthm.2017.10.035). Epub 2017 Oct 30. Review. Erratum in: Heart Rhythm. 2018 Sep 26. PMID: 29097320.

11. Fischer K, Marggraf M, Stark AW, Kaneko K, Aghayev A, Guensch DP, et al. Association of ECG parameters with late gadolinium enhancement and outcome in patients with clinical suspicion of acute or subacute myocarditis referred for CMR imaging. PLoS One. 2020 Jan 10; 15(1): e0227134. (doi: 10.1371/journal.pone.0227134). eCollection 2020. PubMed PMID: 31923225; PubMed Central PMCID: PMC6953836.

12. Buttà C, Zappia L, Laterra G, Roberto M. Diagnostic and prognostic role ofelectrocardiogram in acute myocarditis: A comprehensive review. Ann NoninvasiveElectrocardiol. 2019 Nov 28. (doi: 10.1111/anec.12726). [Epub ahead of print] Review. PubMed PMID: 31778001. 
13. Shabetai R: Acute myopericarditis. Cardiol Clin 1990; 8: 39-44.

14. Castro-Torres Y. Tpeak-Tend/QT: unnuevo predictor electro-cardiográfico de muerte súbita cardíaca. Cardiocore 2014; 49: 86-7.

15. Acar G, Yorgun H, Inci MF, Akkoyun M, Bakan B, Nacar AB, et al. Evaluation of Tp-e interval and Tp-e/QT ratio in patients with ankylosing spondylitis. Mod Rheumatol 2014; 24: 27-30.

16. Antzelevitch C, Oliva A. Amplification of spatial dispersion of repolarization underlies sudden cardiac death associated with catecholaminergic polymorphic VT, long QT, short QT and Brugada syndromes. J Intern Med 2006; 259: 48-58.

17. Antzelevitch C, Shimizu W. Cellular mechanisms underlying the long QT syndrome. Curr Opin Cardiol 2002; 17: 43-51.

18. Castro-Torres Y. Tpeak-Tend/QT: unnuevo predictor electro cardiográfico de muerte súbita cardíaca. Cardiocore 2014; 49: 86-7.

19. Schouten EG, Dekker JM, Meppelink P, et al. QT interval prolongation predicts cardiovascular mortality in an apparently healthy population. Circulation 1991; 84: 1516-23.

20. Aaronson KD, Schwartz JS, Chen TM, et al. Development and prospective validation of a clinical index to predict survival in ambulatory patients referred for cardiac transplant evaluation. Circulation 1997; 95: 2660-7.
21. Ucar FM, Ozturk C, Yılmaztepe MA. Evaluation of Tp-e interval, Tp-e/QT ratioand Tp-e/QTc ratio in patients with acute myocarditis. BMC CardiovascDisord.2019 Oct 22; 19(1): 232. (doi: 10.1186/s12872-019-1207-z). PubMed PMID: 31640548; PubMed Central PMCID: PMC6805629.

22. Assessment of repolarization abnormalities in baseline electrocardiograms of patients with myocarditis. Güneş HM, Babur Güler G, Güler E, et al. Turk J Med Sci. 2017 Nov 13; 47(5): 1333-9. (doi: 10.3906/sag-1612-39).

23. Sharma AN, Stultz JR, Bellamkonda N, Amsterdam EA. Fulminant Myocarditis: Epidemiology, Pathogenesis, Diagnosis, and Management. Am J Cardiol. 2019; 124(12): 1954-60. (doi: 10.1016/j.amjcard.2019.09.017).

24. Kato S, Morimoto S, Hiramitsu S, et al. Risk factors for patients developing a fulminant course with acute myocarditis. Circ J 2004; 68: 34-9.

25. Crişan S, Tint D, Petrescu L. Therapeutic Advances in Emergency Cardiology: A Focus on Acute Myocarditis. Am J Ther. 2019 Mar/Apr; 26(2): e294-e300. (doi: 10.1097/MJT.0000000000000921). Review. PubMed PMID: 30839378.

26. Gironès N, Carbajosa S, Guerrero NA, Poveda C, ChillónMarinas C, Fresno M. Global metabolomic profiling of acute myocarditis caused by Trypanosoma cruzi infection. PLoS Negl Trop Dis. 2014 Nov 20; 8(11): e3337. (doi: 10.1371/journal.pntd.0003337). eCollection 2014 Nov. PubMed PMID: 25412247; PubMed Central PMCID: PMC4239010.

27. Dominguez F, Kühl U, Pieske $B$, et al. Update on myocarditis and inflammatory cardiomyopathy: reemergence of endomyocardial biopsy. Rev Esp Cardiol (Engl Ed). 2016; 69: 178-87. 